\title{
SHC1 wt Allele
}

National Cancer Institute

\section{Source}

National Cancer Institute. SHC1 wt Allele. NCI Thesaurus. Code C52429.

Human SHC1 wild-type allele is located in the vicinity of $1 \mathrm{q} 21$ and is approximately $12 \mathrm{~kb}$ in length. This allele, which encodes SHC-transforming protein 1, is involved in the coordination of activated growth factor receptors with their respective intracellular signaling pathways. 